\title{
The variability of conditions of carbonate allocation on the example of a small flow-through Lęczna-Włodawa lake (Eastern Poland)
}

\author{
Beata Ferencz $\cdot$ Jarosław Dawidek
}

Received: 27 January 2014 / Accepted: 1 July 2014 / Published online: 22 July 2014

(C) The Author(s) 2014. This article is published with open access at Springerlink.com

\begin{abstract}
A synthetic index LSI (Langelier Saturation Index) was calculated to analyze conditions of carbonates allocation. The higher LSI value, positive or negative, the better conditions to deposition or chemical denudation, respectively. Physical-chemical research was carried out in the lake-catchment system of Lake Syczyńskie, located in the border zone of Polish Lowland and Lublin Upland. The data were collected during the three water years 2007-2009. A hydro-chemical state of products of $\mathrm{CaCO}_{3}$ dissociation in waters was close to the equilibrium for most of the year. Values of the LSI ranged from -0.08 to 1.44 in the water of the catchment under study. The highest LSI values were observed in the lake water. The lowest LSI values occurred in waters of the inlet originated from a Cretaceous spring. Allocation conditions were established along inlet-lake-outlet transect. A decrease of carbonates translocation along the transect was typical for the Lake Syczyńskie and it occurred in all seasons. A clear seasonality of the carbonate equilibrium state was observed in the lake-catchment system under study. Results showed that inlet of groundwater determined transport of products of calcium and magnesium carbonate dissociation in the catchment Lake Syczyńskie. The most stable chemical conditions were observed in winter, which resulted from an intense groundwater inflow. The least stable conditions
\end{abstract}

\footnotetext{
B. Ferencz $(\bowtie)$

Department of Landscape Ecology and Nature Conservation, University of Life Sciences, Akademicka 13, 22-950 Lublin, Poland

e-mail: beata.ferencz@up.lublin.pl

J. Dawidek

Department of Hydrology, Maria Curie-Skłodowska University,

Aleja Kraśnicka 2 cd, 20-718 Lublin, Poland

e-mail: jaroslaw.dawidek@ poczta.umcs.lublin.pl
}

occurred in spring, in which season conditions of carbonates allocations were modified by precipitation and/or surface runoff.

Keywords Aggressiveness - Bicarbonates . Carbonate equilibrium · Groundwater inflow . Langelier Saturation Index

\section{Introduction}

Carbon, like other elements, characterizes continuous global cycle which brings about changes of its speciation of occurrence. In temperate areas in carbonate terrains dissolved inorganic carbon (DIC) is the dominate form of aquatic carbon. It results from a soil respiration, C weathering, and groundwater flow (Finlay et al. 2009; Stets et al. 2009). Inland waters play a very important role in global carbon cycle (Cole et al. 1994; Dean and Gorham 1998; Battin et al. 2008) and lakes are areas of active transport, transformation, and retention of carbon derived from the watersheds (Von Wachenfeldt and Tranvik 2008; Tranvik et al. 2009).

The paper presents a part of the global carbon cycle expressed as a carbonate equilibrium state, which includes the products of dissociation of $\mathrm{CaCO}_{3}$ and $\mathrm{CO}_{2}$ and the $\mathrm{pH}$ is an indicator of the condition of the carbonate equilibrium.

The carbonate equilibrium state of an aquatic environment is a very important issue within geosciences. An understanding of carbonate equilibria is essential in geologic studies of surface and groundwater chemistry, as well as global climate (Andersen 2002; Krinner 2003). Parameters such as alkalinity, DIC, partial pressure of carbon dioxide $p \mathrm{CO}_{2}$, or $\mathrm{pH}$ values can be used to determine 
carbonate equilibrium (Stumm and Morgan 1996; Paquay et al. 2007; Hunt et al. 2011). Migration of products of carbonates dissociation in the aquatic environment is an important and interesting research problem (Telmer and Vezier 1999; Humborg et al. 2000). The evaluation of the degree of buffering of lake water also allows for determining the possibility of ionic transformation in the basin. The process of ionic transformation and translocation within lake-catchment systems is modified by changes in those conditions which are typical of different hydrochemical systems. The process of carbonate dissolution in the lake basin is not the only existing hydro-geochemical system in the waters. With a full awareness of the existence of those ions-products of the dissociation of minerals which are foreign with respect to the carbonate system (e.g., $\mathrm{Na}^{+}, \mathrm{K}^{+}, \mathrm{Fe}^{2+}, \mathrm{Cl}^{-}$, and $\mathrm{SO}_{4}{ }^{2-}$ ), in the waters of the lake under study, it is safe to assume the existence of a system consisting only of $\mathrm{H}_{2} \mathrm{O}, \mathrm{CO}_{2}$, and $\mathrm{CaCO}_{3}$ (Cole and Caraco 2001; Sobek et al. 2005). It reflects the actual ionic translocation in the environment, from the initial water stage through the zone of its terrestrial contact with carbonates, up to the local drainage base that is a lake basin. An important parameter that characterizes the chemical state of natural water is corrosiveness. The corrosiveness of water depends on many physical, chemical, and microbiological parameters (e.g., temperature, $\mathrm{pH}$, partial pressure of $\mathrm{CO}_{2}$ etc.) (Davil et al. 2009). Stability indexes are popular regarding calcium carbonate, such as the Langelier Saturation Index (LSI) (Dąbrowski et al. 2010; Al-Zalzaleh and Cruz 2011; Gupta et al. 2011). A value of the index equal zero indicate a carbonate equilibrium state of water. Positive value of LSI is observed in supersaturated with carbonates waters, whereas negative in environments where chemical denudation occur.

As far as natural processes are concerned, of primary importance is the corrosiveness of water over rocks which build the lake catchment (chemical denudation, allocations of ions, and the degree of modification of the ionic composition of water). For waters of the border zone of the Polish Lowlands and Central Polish Uplands it can be simply applied to the analysis of the impact of water on dissolving calcium carbonate $\left(\mathrm{CaCO}_{3}\right)$. Given the high concentration of calcium in the waters of Lake Syczyńskie (Ferencz et al. 2014), it is easier to understand the process of how corrosiveness shapes the carbonate equilibria of lake waters. Calcium ions in a complex but significant way (simultaneously and oppositely) have an impact on the increase of both water $\mathrm{pH}$ and the level of $\mathrm{H}_{2} \mathrm{CO}_{3}$ (Antony et al. 2011). The aim of this study was to determine the seasonal conditions of the allocation of carbonates in the flow-through Lake Syczyńskie. It was assumed that in the water body adjacent to the carbonate physiographical unit of Upland Lublin, an underground basin supply plays a decisive role in the transport of products of calcium and magnesium carbonate dissociation.

\section{Study area}

Lake Syczyńskie belongs to a group of small water bodies. A shallow and round lake basin (Fig. 1) was created in a carbonate peat environment, on Cretaceous rock wastes (Borowiec 1990).

The lake is situated at an altitude of $179 \mathrm{~m}$ a.s.l. and it occupies the southwestern part of its catchment area. The lake under study is drained southwest, toward the Świnka River via a ditch which is $2 \mathrm{~m}$ high and $1 \mathrm{~m}$ wide. The flow-through lake basin is supplied with water of four inlets, the largest of which originates in a spring that is located at the foot of Chełm Hills and has the highest hydrological activity among the inlets and it was perennial. The other inlets were intermittent or episodic.

Lake Syczyńskie is adjacent to the east of Pliocene denudation hills, the surface of which is covered with a thick Pleistocene sediment layer (Wilgat 1991). The denudation mountains in the area are the cumulative result of Cretaceous substrates. They are not high (up to $20 \mathrm{~m}$ in relative height), and gently rise above the flat area of the Łęczna-Włodawa Lake District. The relief of the Lake Syczyńskie catchment area $\left(2.66 \mathrm{~km}^{2}\right)$ is very diverse (Fig. 1). The denivellations are up to $46 \mathrm{~m}$, which is the highest value among the Łęczna-Włodawa lakes. The catchment area of the lake is dual in nature in terms of its topographic features. The northern and northwest part is flat, with denivellations of $<3.5 \mathrm{~m}$, whereas the eastern and northeast part is an upland area with higher denivellations. That duality determines the rate of lake basin supply. The eastern, larger part of the catchment area, with a high proportion of sandy sediments, is a hydrologically privileged zone.

\section{Materials and methods}

Field measurements were carried out during the water years 2007-2009. Water samples for chemical analyses were collected once a month, $1 \mathrm{~m}$ below the surface from the deepest part of the lake and at 0.8 of maximum depth of a current zone from streams that supply and drain Lake Syczyńskie basin. Simultaneously with chemical measurements, hydro-meteorological research was carried out (water levels and flow rates, the amount of precipitation), to assess the rate of ion translocation within the lakecatchment system. Water velocity of both the inlet and outlet was measured bimonthly, using a Nautilus 2000 current meter. The number of cross-sections was 
Fig. 1 Scheme of supply and drainage of Lake Syczyńskie

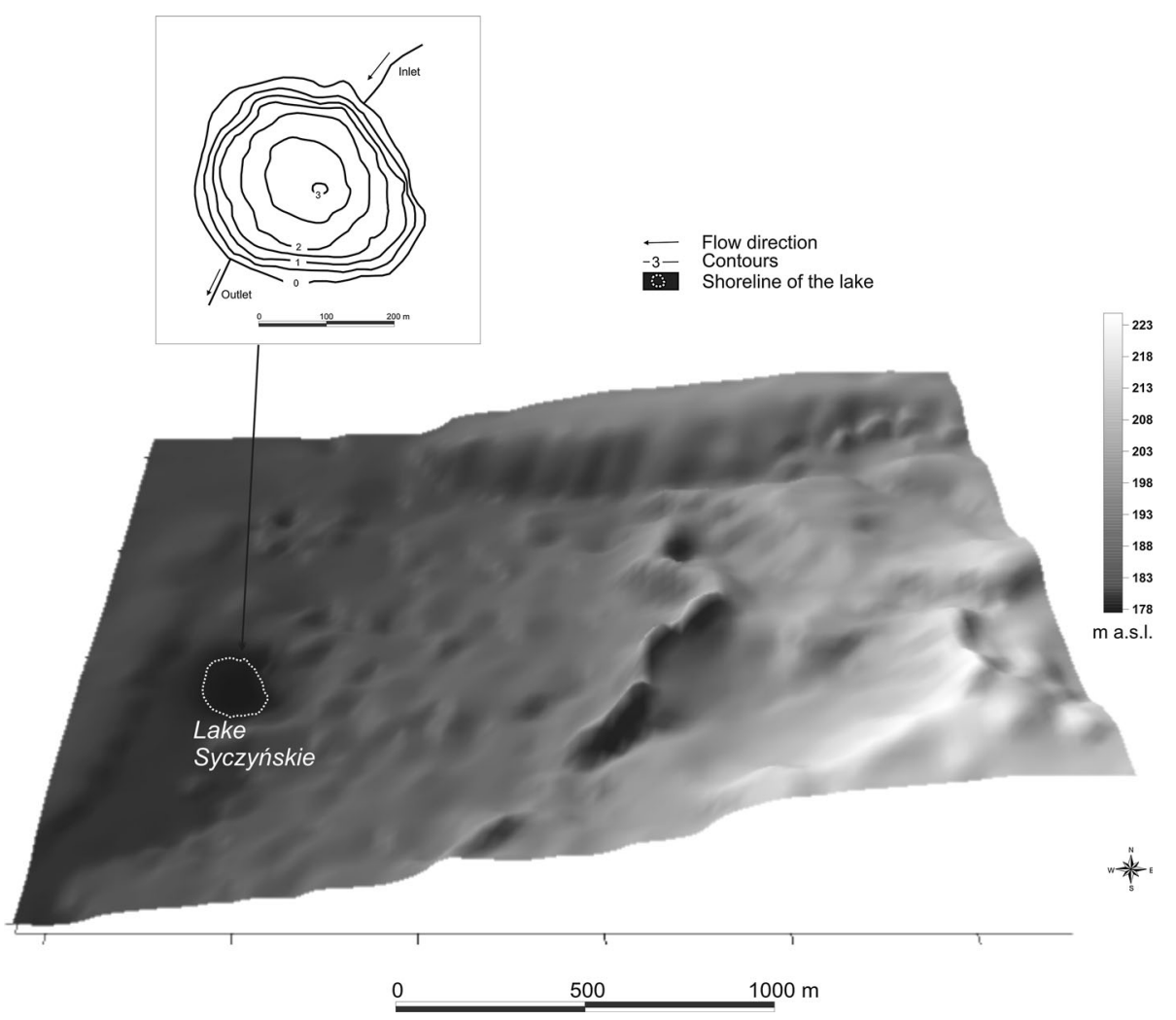

To determine the corrosive or non-corrosive properties of the water, a common index describing the state of the calcium carbonate equilibrium of sampled water was used. The equilibrium of the water was described via an LSI index. It was the difference between the $\mathrm{pH}$ measured in situ and the $\mathrm{pH}$ of the equilibrium of the carbonate system in specific hydro-geochemical conditions (Melidis et al. 2007; Kumar et al. 2011).

Therefore:

$\mathrm{LSI}=\mathrm{pH}-\mathrm{pH}_{\mathrm{s}}$

where: $\mathrm{pH}$ - the actual measured value, $\mathrm{pH}_{\mathrm{s}}$ - the saturation $\mathrm{pH}$ of water with respect to $\mathrm{CaCO}_{3}$; calculated from the formula:

$\mathrm{pH}_{\mathrm{s}}=(9.3+A+B)-(C+D)$

where: $A, B, C$, and $D$ are the empirical constants based on total dissolved solids (TDS), water temperature ${ }^{\circ} \mathrm{C}$, calcium hardness, and total alkalinity

$A=\frac{\log _{10}[\mathrm{TDS}]-1}{10}$

$B=-13.12 \log _{10}\left(t^{\circ} K\right)+34.55$

$C=\log _{10}\left[\mathrm{Ca}^{2+}\right.$ converted into units of weight $\left.\mathrm{CaCO}_{3}\right]-0.4$

$D=\log _{10}[$ alkalinity converted to conventional weighing units $\mathrm{CaCO}_{3}$ ] 
Differences of LSI values were calculated to estimate carbonates translocation conditions whiting the lakecatchment system. Lakeshore conditions were determined with relation to the inlet as a difference of lake and inlet LSI values (L-I). The conditions of carbonates allocation on the exit of the system were calculated as a difference of outlet and lake LSI values (O-L) (Fig. 4).

\section{Results}

Hydro-meteorological conditions

From a hydro-chemical point of view, along with the sum of precipitation, time, and frequency of occurrence is an essential factor. During the time period under study, the most frequent were daily sums of precipitation not exceeding $0.1 \mathrm{~mm}$ (715 days). Precipitation sums that ranged from 1.1 to $5.0 \mathrm{~mm}$ were measured 162 days. Other ranges were characterized by an equal frequency of occurrence, from 50 days $(>10.0 \mathrm{~mm})$ to 59 days $(0.2-0.5 \mathrm{~mm})$. The distribution of precipitation values showed a high variability per water year. Precipitation amounted to $1.0-5.0 \mathrm{~mm}$ occurred usually in the cold season. On the other hand, torrential rainfall $(>10 \mathrm{~mm})$ was the most frequent in the warm season. Total daily precipitation measuring in the range of 5.1-10.0 mm was usually gauged in transitional seasons, between autumn and winter, and/or winter and spring (Fig. 2).

The flow rates, which are derived from atmospheric precipitation, showed a clear seasonal variability. The average monthly inflow ranged from 4.35 to $16.88 \mathrm{~L} \mathrm{~s}^{-1}$, whereas the outflow from 4.98 to $50.85 \mathrm{~L} \mathrm{~s}^{-1}$. The lowest tributary values were recorded from May to October, and the highest from November to April (Table 1). The notably low outflow distribution in the summer-autumn period was similar to the inflow; however, maximum outflows showed

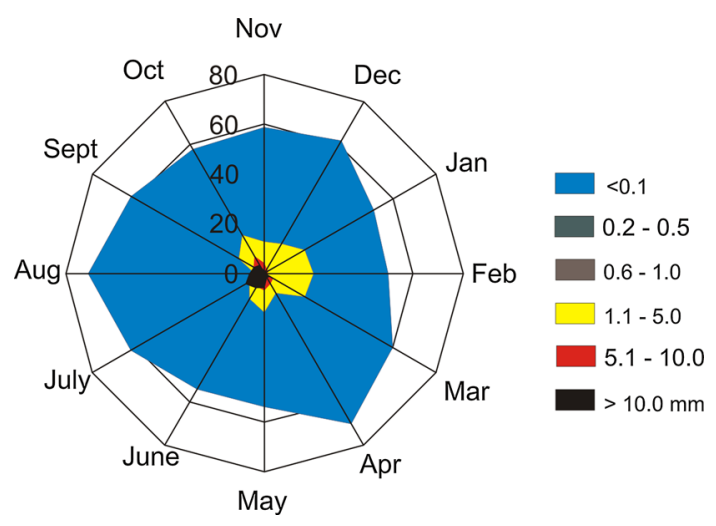

Fig. 2 Frequency of precipitation occurrence in the selected ranges of daily sums (mm) a displacement of 3 months (February-April) with reference to maximum inflows. Underground supply and drainage values showed a clear seasonal variability. Underground supply in the cold season (Nov-Apr) was several times higher than in the warm season (May-Oct). Monthly mean underground inflow rates to the lake basin, during the time period under study, ranged from $3.88 \mathrm{~L} \mathrm{~s}^{-1}$ in October to $14.47 \mathrm{~L} \mathrm{~s}^{-1}$ in February. Maximum underground inflow and outflow occurred in winter-spring months (February-March). The lowest underground flow was measured in October, while the highest was observed in July (Table 1).

\section{Hydro-chemical conditions}

The hydro-chemical conditions of the waters of the area under study showed a moderate state of saturation of the products of calcium carbonate and magnesium dissociation, throughout the study period (Table 2).

The highest concentrations of the geogenic ions, $\mathrm{Ca}^{2+}$ and $\mathrm{HCO}_{3}{ }^{-}$usually occurred (except spring) in the waters of inflow. Changes in $\mathrm{pH}$ value of water flowing through the lake catchment generally showed pattern lake $>$ outflow $>$ inflow. The highest concentrations of $\mathrm{Mg}^{2+}$, and the highest $\mathrm{pH}$ values were observed (except spring) in the lake waters.

A clear seasonality of the carbonate equilibrium state was observed in each year under study. Transformations of carbonate equilibrium state of water inflowing and draining the lake were characterized by a marked increase in alkalinity from summer to winter (Fig. 3a, c). Spring was the only period in which the changes were short-lived, and multi-directional, with no clear trend observed. The conditions for creating and maintaining the carbonate equilibrium in the lake waters were different. During the summer and autumn, warm lake water showed a high hydro-chemical stability, whereas during spring it was significantly lower (Fig. 3b).

Values of the LSI ranged from -0.08 to 1.44 in the water of the catchment under study (Table 2). The waters of the inlet and lake basin were non-aggressive for most of the year. The index value in outflow water, however, was consistently positive. The role of the lake basin in shaping changes in the hydro-chemical translocations of water should be defined as being diverse. Four specific ways to transform the phenomenon spatially were distinguished. A decrease in LSI differences values along the transect inflow-lake-outflow was typical of the lake under study (Fig. 4). It was observed in all seasons. Different patterns of changes in allocations were also noted.

They appeared briefly and were clearly seasonal. Two types were observed in winter. The first was characterized by a stability of the LSI along the aforementioned transect 
Table 1 Monthly flow rates values of outlet and inlet (total and underground) in the Lake Syczyńskie catchment $\left(\mathrm{L} \mathrm{s}^{-1}\right)$

\begin{tabular}{|c|c|c|c|c|c|c|}
\hline \multirow[t]{2}{*}{ Month } & \multicolumn{3}{|l|}{ Inlet } & \multicolumn{3}{|l|}{ Outlet } \\
\hline & Minimum & Mean & Maximum & Minimum & Mean & Maximum \\
\hline \multicolumn{7}{|l|}{ Total } \\
\hline Nov & 7.91 & 12.49 & 21.17 & 5.11 & 12.09 & 21.60 \\
\hline Dec & 6.88 & 12.75 & 19.39 & 6.83 & 14.39 & 21.60 \\
\hline Jan & 6.88 & 14.56 & 22.44 & 5.50 & 19.66 & 35.71 \\
\hline Feb & 6.88 & 16.88 & 28.27 & 21.60 & 49.62 & 91.55 \\
\hline Mar & 7.91 & 16.30 & 28.27 & 20.25 & 50.85 & 91.55 \\
\hline Apr & 7.91 & 13.26 & 20.45 & 23.03 & 34.73 & 61.24 \\
\hline May & 3.91 & 9.50 & 15.65 & 8.44 & 18.23 & 35.71 \\
\hline Jun & 4.51 & 7.01 & 11.94 & 2.80 & 9.39 & 23.03 \\
\hline Jul & 3.91 & 8.81 & 20.45 & 2.04 & 7.57 & 21.60 \\
\hline Aug & 4.51 & 6.17 & 13.68 & 1.36 & 4.98 & 12.75 \\
\hline Sep & 4.51 & 7.15 & 15.65 & 1.36 & 8.37 & 21.60 \\
\hline Oct & 2.93 & 4.35 & 6.88 & 5.45 & 8.42 & 12.75 \\
\hline \multicolumn{7}{|c|}{ Underground } \\
\hline Nov & 7.66 & 10.02 & 11.35 & 6.22 & 9.69 & 12.55 \\
\hline Dec & 10.05 & 11.67 & 13.16 & 11.65 & 13.61 & 15.33 \\
\hline Jan & 11.90 & 12.82 & 14.56 & 13.14 & 17.82 & 29.37 \\
\hline Feb & 12.32 & 14.47 & 16.18 & 33.55 & 43.67 & 50.11 \\
\hline Mar & 11.93 & 13.34 & 14.24 & 37.53 & 43.21 & 46.67 \\
\hline Apr & 9.31 & 11.39 & 12.65 & 21.17 & 30.83 & 40.66 \\
\hline May & 5.00 & 7.61 & 9.28 & 10.36 & 16.31 & 22.81 \\
\hline Jun & 5.03 & 5.76 & 7.93 & 3.31 & 5.91 & 10.11 \\
\hline Jul & 4.21 & 6.13 & 8.22 & 2.72 & 3.26 & 4.00 \\
\hline Aug & 4.68 & 5.11 & 5.19 & 3.06 & 3.48 & 4.10 \\
\hline Sep & 4.76 & 5.16 & 5.59 & 3.86 & 5.37 & 7.47 \\
\hline Oct & 2.58 & 3.88 & 5.49 & 3.91 & 6.87 & 8.29 \\
\hline
\end{tabular}

without significant changes in water quality. The second type showed a reduction of the LSI values after passing the lake basin. An extremely large decrease in denudation conditions of water in a short time occurred in summer. Figure 5 presents a statistical relationship between calculated LSI values of inlet and outlet and the groundwater lake inflow and outflow (Qg).

In both cases it was evident that higher the flow rate, the higher was the inclination of the carbonate equilibrium into the deposition.

\section{Discussion}

Water of Lake Syczyńskie is hard, and represents a type $\mathrm{HCO}_{3}-\mathrm{Ca}$. Hard and saline lakes constitute almost half of the volume of all inland waters in the world (Wetzel 2001). Duarte et al. (2008) observed an impact of changes in $\mathrm{CO}_{2}$ on the $\mathrm{pH}$ of the lakes water. To be precise, the $\mathrm{pH}$ value is an indicator of the equilibrium state of carbonates, which besides the different forms of
$\mathrm{CO}_{2}$ content also affects the concentration of dissociation products of $\mathrm{CaCO}_{3}$.

It is assumed that a high $\mathrm{pH}$ favors water supersaturation and precipitation of calcium carbonates, whereas the lowering of the $\mathrm{pH}$ causes $\mathrm{CO}_{2}$ degassation (Finlay et al. 2009) and reduction of the concentration of carbon dioxide in water, associated with $\mathrm{HCO}_{3}$ (Duarte et al. 2008). In the case of Lake Syczyńskie, $\mathrm{pH}$ changes showed a clear seasonality (Table 2).

Water of a hypertrophic Lake Syczyńskie is supersaturated with $\mathrm{CO}_{2}$ and shows periodic degassation into the atmosphere. It has been indicated by a change in the LSI values along the transect inflow-lake-outflow (Table 2). Many studies indicate that the $\mathrm{CO}_{2}$ emitted from lakes is mainly derived from in-lake respiration (Jansson et al. 2000; Sobek et al. 2005). The highest observed level of free $\mathrm{CO}_{2}$ degassing from the basin of the Lake Syczyńskie occurred in summer. However, in winter, the deflection of the carbonate equilibrium state toward an increase of the deposition of $\mathrm{CaCO}_{3}$ increased role of $\mathrm{CO}_{2}$ bound in carbonates (Fig. 3). 
Table 2 Values of selected physical-chemical parameters of waters

\begin{tabular}{|c|c|c|c|c|c|c|c|c|c|}
\hline \multirow[t]{2}{*}{ Parameter } & \multirow[t]{2}{*}{ Unit } & \multicolumn{2}{|c|}{ Autumn } & \multicolumn{2}{|c|}{ Winter } & \multicolumn{2}{|c|}{ Spring } & \multicolumn{2}{|c|}{ Summer } \\
\hline & & Min & Max & Min & Max & Min & $\operatorname{Max}$ & Min & $\operatorname{Max}$ \\
\hline \multicolumn{10}{|l|}{ Main inlet } \\
\hline $\mathrm{Ca}^{2+}$ & meq $\mathrm{L}^{-1}$ & 4.95 & 5.90 & 5.47 & 6.43 & 2.73 & 5.15 & 4.52 & 5.69 \\
\hline $\mathrm{Mg}^{2+}$ & meq $\mathrm{L}^{-1}$ & 0.12 & 0.62 & 0.14 & 0.42 & 0.21 & 2.52 & 0.04 & 1.49 \\
\hline $\mathrm{HCO}_{3}{ }^{-}$ & meq $\mathrm{L}^{-1}$ & 4.98 & 6.00 & 4.93 & 5.53 & 4.49 & 4.9 & 4.15 & 4.25 \\
\hline $\mathrm{pH}$ & & 7.28 & 7.81 & 7.67 & 7.93 & 7.42 & 7.74 & 7.36 & 7.53 \\
\hline $\mathrm{EC}$ & $\mu \mathrm{S} \mathrm{cm}-1$ & 454 & 566 & 522 & 589 & 400 & 480 & 436 & 444 \\
\hline TDS & $\mathrm{mg} \mathrm{L}^{-1}$ & 294 & 454 & 348 & 494 & 288 & 305 & 427 & 452 \\
\hline \multicolumn{10}{|l|}{ Lake } \\
\hline $\mathrm{Ca}^{2+}$ & meq $\mathrm{L}^{-1}$ & 3.67 & 4.97 & 4.97 & 5.56 & 4.78 & 6.19 & 3.90 & 5.51 \\
\hline $\mathrm{Mg}^{2+}$ & meq $\mathrm{L}^{-1}$ & 0.38 & 2.88 & 0.20 & 0.64 & 0.06 & 0.66 & 0.22 & 1.29 \\
\hline $\mathrm{HCO}_{3}{ }^{-}$ & meq $\mathrm{L}^{-1}$ & 3.49 & 4.67 & 4.78 & 5.02 & 4.90 & 5.46 & 3.62 & 4.22 \\
\hline $\mathrm{pH}$ & & 8.00 & 8.28 & 7.72 & 8.52 & 7.78 & 8.19 & 8.03 & 8.85 \\
\hline $\mathrm{EC}$ & $\mu \mathrm{S} \mathrm{cm}-1$ & 465 & 521 & 522 & 589 & 556 & 587 & 394 & 475 \\
\hline TDS & $\mathrm{mg} \mathrm{L}^{-1}$ & 432 & 525 & 348 & 494 & 316 & 396 & 368 & 452 \\
\hline \multicolumn{10}{|l|}{ Main outlet } \\
\hline $\mathrm{Ca}^{2+}$ & meq $\mathrm{L}^{-1}$ & 4.50 & 5.32 & 4.06 & 6.52 & 4.85 & 5.13 & 4.13 & 5.36 \\
\hline $\mathrm{Mg}^{2+}$ & meq $\mathrm{L}^{-1}$ & 0.50 & 1.55 & 0.01 & 0.89 & 0.29 & 0.42 & 0.11 & 0.60 \\
\hline $\mathrm{HCO}_{3}{ }^{-}$ & meq $\mathrm{L}^{-1}$ & 4.58 & 4.77 & 4.94 & 5.36 & 4.61 & 4.82 & 3.60 & 4.22 \\
\hline $\mathrm{pH}$ & & 7.49 & 7.93 & 7.55 & 8.20 & 7.47 & 7.94 & 7.46 & 7.94 \\
\hline $\mathrm{EC}$ & $\mu \mathrm{S} \mathrm{cm}^{-1}$ & 471 & 521 & 532 & 595 & 460 & 606 & 394 & 475 \\
\hline TDS & $\mathrm{mg} \mathrm{L}^{-1}$ & 315 & 492 & 306 & 502 & 306 & 319 & 366 & 448 \\
\hline
\end{tabular}
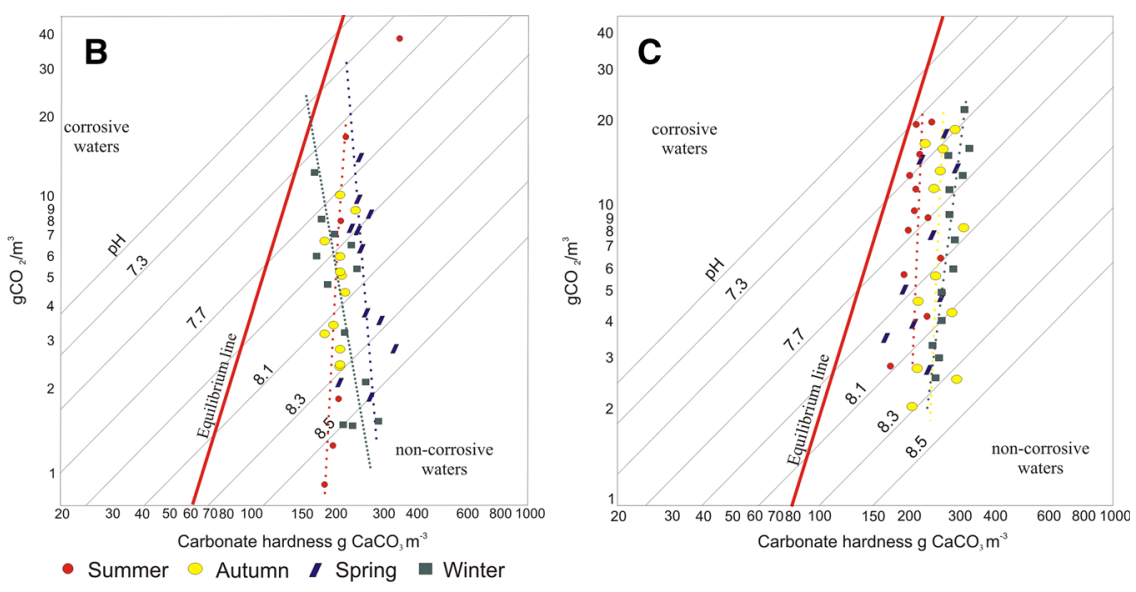

Fig. 3 Seasonal state of carbonate equilibrium of water $\mathbf{a}$ inlet, $\mathbf{b}$ lake, $\mathbf{c}$ outlet

The typical seasonality of the process of shaping the carbonate equilibrium, observed in the waters of the area under study, resulted from relationships between the genetically various forms of the basin supply (surface, underground). A seasonality of river outflow as well as duration of ice and snow cover modifies the carbon flow from the watershed (Weyhenmeyer and Karlsson 2009). A factor stabilizing the carbonate equilibrium state was the underground inflow of alkaline water from carbonate rocks that made up the lake-catchment area. Lithology of the catchment played an important role in shaping water quality (Sheikh et al. 2014, Krishnakumar et al. 2014). The importance of the geological structure in the shaping of water quality has been observed especially during periods of intensive groundwater recharge, when the highest concentrations of geogenic ions were observed in the inflow water. Dawidek et al. (2009) indicated the hydrologically dominant role of the underground supply of Lake 
Syczyńskie. A lack of distinct patterns of changes of physical-chemical parameters along the transect in spring was a result of thawing snow retained in the lake catchment. The strong association of groundwater recharge to Lake Syczyńskie with conditions of the carbonate allocation showed coefficients of correlation ' $r$ ' which exceeded 0.8 . Howden et al. (2010) showed correlation between chemical concentration of major ions and groundwater in the catchments with Chalk aquifers. The relationship was also confirmed by the changeability of the LSI on the lake basin inlet-outlet transect. Values of the difference between LSI, presented in Fig. 4 also include the role of inlake processes (autochthonous production, microbial degradation, photochemical decay, and sedimentation) whose integral part is, for example, carbon sequestration in the sediments. Cole et al. (2007) stressed the importance of bottom sediments and their quantitative role described Dean and Gorham (1998).

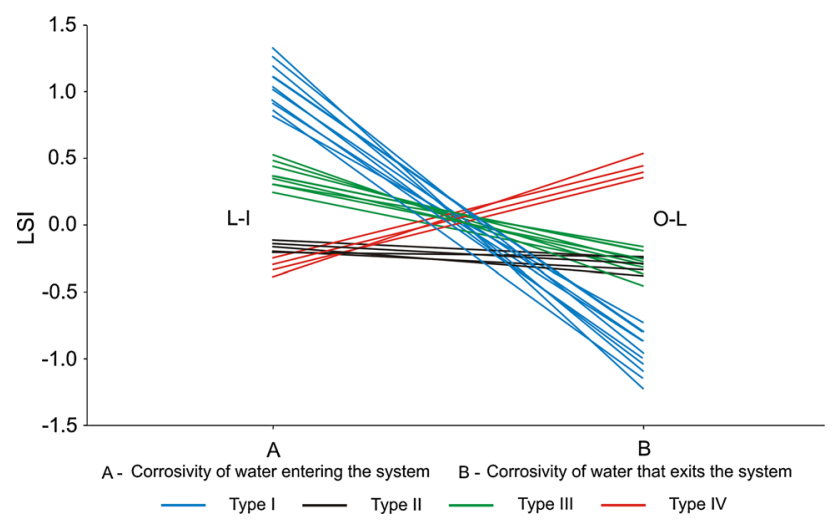

Fig. 4 A potential of carbonates ionic allocation along inlet-lakeoutlet transect in the selected samples. Type I: Nov 06, Dec 06, Mar 07, Apr 07, Jun 07, May 08, Sep 08, Apr 09, Aug 09, Oct 07, 09; Type II: Jan 07, 08, Feb 08, 09, Nov 08; Type III: Dec 07, 08, 09, Jan 07, 08, 09, Feb 07, 08, 09; Type IV: Jul 07, 09, Aug 07, 08
Factors that modified the hydro-chemical properties of water were: atmospheric precipitation (intensity and type of precipitation), surface runoff, and water temperature. An influence of the type of lake supply (atmospheric deposition and/or groundwater inflow) has been previously described by Striegl et al. (2001) and Bade et al. (2004). Physical-chemical parameters of waters as well as LSI values were also influenced by physical-biochemical processes. The mass appearance of algae has been observed in Lake Syczyńskie in all seasons. Phytoplankton photosynthesis led to increase of $\mathrm{pH}$ in lake waters (Toporowska and Pawlik-Skowrońska 2014), worsen light conditions and as a consequence simplified water biocenosis (Adamczuk 2012). The pattern of $\mathrm{pH}$ changes along the transect inflow-outflow was characterized by higher $\mathrm{pH}$ in the outlet than in inlet, which was consistent with other studies (Billett and Moore 2008).

The water that supplied and drained the lake basin was characterized by the highest level of non-corrosiveness during the winter, this being associated with intense underground feeding at that time. The most corrosive level of the water was observed in summer, this being a result of an increase in atmospheric precipitation, high water temperature, which favored the degassing of $\mathrm{CO}_{2}$ and a retention of calcium and magnesium in the water solution (Billett and Moore 2008; Bates et al. 2013). The intermediate stage was noted in autumn. The most variable conditions in the carbonic equilibrium occurred in spring in the inflow and outflow waters. This was due to the variable from year to year amount of atmospheric precipitation and the size and genetic structure (quick flow, base flow) of the outflow in this period. Spring is a period when physico-chemical processes can act in either direction, increasing/decreasing $p \mathrm{CO}_{2}, \mathrm{pH}$, equilibrium state, due to the ice melt, precipitation or riverine input (Bates et al. 2013). Tranvik et al. (2009) pointed out the significant role of catchment hydrology (the relationship between runoff and underground drainage) and precipitation
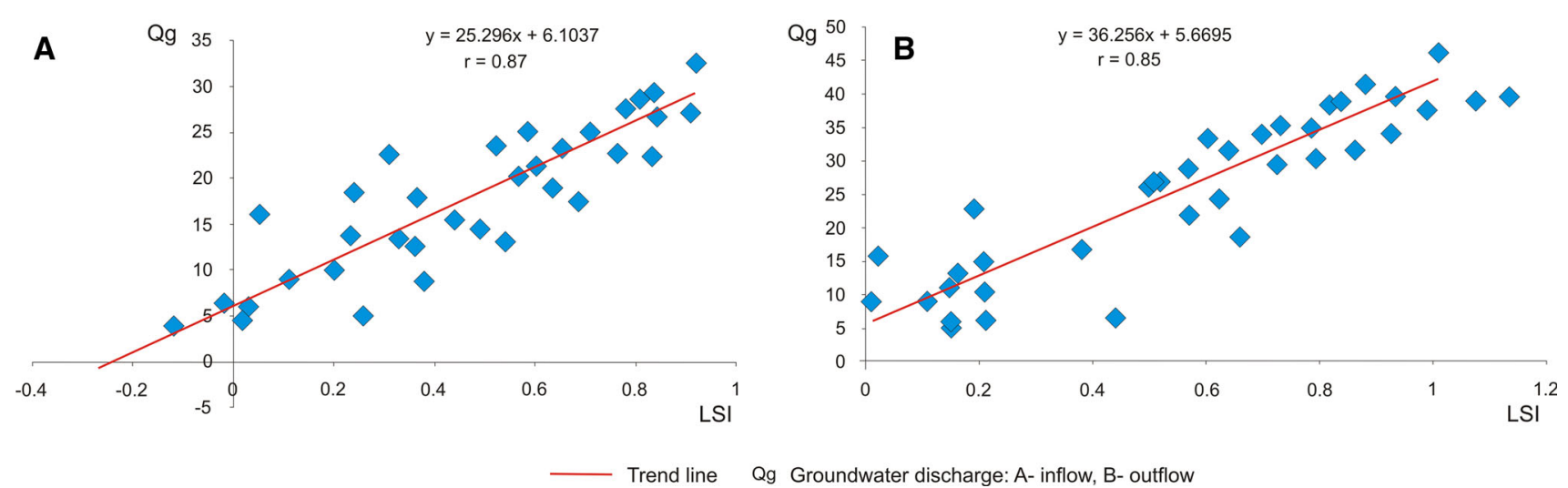

Fig. 5 Statistical relation between LSI value and underground discharge of $\mathbf{a}$ inlet, $\mathbf{b}$ outlet 
on the quantity of carbon derived to the system. The gradient of hydro-chemical changes in the inlet water in spring (variable over a wide range, from highly non-corrosive to corrosive waters) resulted from thaws and/or heavy rains (i.e., a low pH of water) (Driscoll et al. 2003).

The carbonate equilibrium state in the outlet waters showed the most volatility in spring; there were no definable trends observed. The outlet water that constitutes the final stage in the transformation was modified by both catchment (precipitation, surface, and underground inflow) and in-lake processes. Similarly to other lakes, representing the hydro-geochemical conditions of an open system, a continuous and unlimited exchange of both mass and energy occurred, and the dissolution and dissociation of the carbonate minerals that build the lake-catchment area took place in the presence of $\mathrm{CO}_{2}$, the partial pressure of which equals the partial pressure of $p \mathrm{CO}_{2}$ atm (Rouse et al. 2002; Valdivia 2006). The dissolution of substrates changed the chemical composition of the water (which was accompanied by a $\mathrm{pH}$ increase) and favored allocation of ions (Riebesell 2004; Jensen et al. 2009). The thermodynamic state of the lake waters, which was typical for an open system, could be classified as being stable. With an increase in atmospheric precipitation or runoff, the existing equilibrium, however, underwent a rapid, constant, and multi-directional modification.

The catchments built with carbonate sediments are an important element in the global carbon cycle. The importance of this type of research is connected to the fact that, the lakes are considered an important source of emission of $\mathrm{CO}_{2}$ to the atmosphere (Anderson et al. 1999; Cole and Caraco 1998; Cole et al. 1994; del Giorgio et al. 1999; Dillon and Molot 1997; Kling et al. 1991; Striegl et al. 2001; Wachniew and Rózanski 1997).

\section{Conclusions}

Analysis of a state of carbonate equilibrium in lakecatchment systems is an important issue in processes of shaping ionic allocation. An inclination of lake water properties from hydro-chemical state of equilibrium was observed with reference to macro-elements, but in the wider context it played a role of indicator of the potential (gradient) to ion translocations. During conventional transport of the dissolved solids (with water in the same direction and velocity) identification of the ionic allocations within the hydrosphere with reference to terrestrial carbonates was a good indicator of intensity and seasonality of hydro-chemical limnetic conditions. Underground inflow influenced significantly transport of products of calcium and magnesium carbonate dissociation in winters with lack of thaws and also to a lesser extent in autumn. A clear seasonality of carbonate equilibrium state suggested that the process was modified by different genetic types of lake's supply. The least stable period of carbonates allocation was spring, due to the variability of rainfall and the role of runoff. Favorable conditions for sedimentation of carbonates in summer were determined not only by catchment hydrology but also in-lake processes.

Open Access This article is distributed under the terms of the Creative Commons Attribution License which permits any use, distribution, and reproduction in any medium, provided the original author(s) and the source are credited.

\section{References}

Adamczuk M (2012) Spatial distribution of juvenile and adult stages of limnetic Cladocera in relation to selected environmental factors. J Limnol 71(1):112-118. doi:10.4081/jlimnol.2012.e11

Al-Zalzaleh H, Cruz GD (2011) Assessment of drainage water quality for $\mathrm{CaCO}_{3}$ precipitation using saturation index. Kuwait J Sci Eng 38:93-109

Andersen CB (2002) Understanding carbonate equilibria by measuring alkalinity in experimental and natural systems. J Geosci Educ 50(4):389-403

Anderson LG, Jones EP, Rudels R (1999) Ventilation of the Arctic Ocean estimated by a plume entrainment model constrained by CFCs. J Geophys Res 104:13423-13429

Antony A, Low JH, Gray S, Childress AE, Le-Clech P, Leslie G (2011) Scale formation and control in high pressure membrane water treatment systems: a review. J Membr Sci 383:1-16. doi:10.1016/j.memsci.2011.08.054

Bade DL, Carpenter SR, Cole JJ, Hanson PC, Hesslein RH (2004) Controls of d13CDIC in lakes: geochemistry, lake metabolism, and morphometry. Limnol Oceanogr 49:1160-1172. doi:10. 4319/1o.2004.49.4.1160

Bates NR, Orchowska MI, Garley R, Mathis JT (2013) Summertime calcium carbonate undersaturation in shelf waters of the western Arctic Ocean-how biological processes exacerbate the impact of ocean acidification. Biogeosciences 10:5281-5309

Battin TJ, Kaplan LA, Findlay S, Hopkinson CS, Marti E, Packman AI, Newbold JD, Sabater F (2008) Biophysical controls on organic carbon fluxes in fluvial networks. Nat Geosci 1:95-100. doi:10.1038/ngeo101

Billett MF, Moore TR (2008) Supersaturation and evasion of $\mathrm{CO}_{2}$ and $\mathrm{CH}_{4}$ in surface waters at Mer Bleue peatland, Canada. Hydrol Processes 22:2044-2054

Borowiec A (1990) Peatbogs of the Lubelszczyzna region. Lubelskie Towarzystwo Naukowe. Prace Wydziału Nauk o Ziemi i Nauk Górniczych. Monografie 3. PWN, Warsaw

Cole JJ, Caraco NF (1998) Atmospheric exchange of carbon dioxide in a low-wind oligotrophic lake measured by the addition of SF6. Limnol Oceanogr 43:647-656

Cole JJ, Caraco N (2001) Carbon in catchments: connecting terrestrial carbon losses with aquatic metabolism. Mar Freshw Res 52:101-110

Cole JJ, Caraco NF, Kling GW, Kratz TK (1994) Carbon dioxide supersaturation in the surface waters of lakes. Science 265:1568-1570

Cole JJ, Prairie YT, Caraco NF, McDowell WH, Tranvik LJ, Striegl RG, Duarte CM, Kortelainen P, Downing JA, Middelburg JJ, 
Melack J (2007) Plumbing the global carbon cycle: integrating inland waters into the terrestrial carbon budget. Ecosystems 10:171-184. doi:10.1007/s10021-006-9013-8

Dąbrowski W, Buchta R, Dąbrowska B, Mackie RI (2010) Calcium carbonate equilibria in water supply systems. Environ Prot Eng 36(2):75-94

Davil MF, Mahvi AH, Norouzi M, Mazloomi S, Amarluie A, Tardast A, Karamitabar Y (2009) Survey of corrosion and scaling potential produced water from ilam water treatment plant. World Appl Sci J 7:1-6

Dawidek J, Pęczuła W, Ferencz B (2009) The role of catchment and in-lake processes in shaping trophic conditions of the shallow lake Syczyńskie (Eastern Poland). Ecohydrol Hydrobiol 9(2-4):193-200. doi:10.2478/v10104-010-0011-2

Dean WE, Gorham E (1998) Magnitude and significance of carbon burial in lakes, reservoirs, and peatlands. Geology 26:535-538

del Giorgio PA, Cole JJ, Caraco NF, Peters RH (1999) Linking planktonic biomass and metabolism to net gas fluxes in northern temperate lakes. Ecology 80:1422-1431

Dillon PJ, Molot LA (1997) Dissolved organic and inorganic carbon mass balances in central Ontario lakes. Biogeochemistry 36:29-42

Driscoll CT, Driscoll KM, Mitchell MJ, Raynal DJ (2003) Effects of acidic deposition on forest and aquatic ecosystems in New York State. Environ Pollut 123:327-336

Duarte CM, Montes C, Cole JJ, Striegl RG, Melack J, Downing JA (2008) $\mathrm{CO}_{2}$ emissions from saline lakes: a global estimate of a surprisingly large flux. J Geophys Res 113:G04041. doi:10.129/ 2007JG000637

European ISO EN Rule 748, Measurement of liquid flow in open channels-velocity-area methods, Reference number ISO 748: 1997 (E), International Standard, 1997

Ferencz B, Dawidek J, Toporowska M (2014) Hydro-chemical vs. biological conditions of the functioning of three shallow ŁęcznaWłodawa lakes. Water Environ Res 86(3):269-276. doi:10.2175/ $106143013 X 13807328849332$

Finlay K, Leavitt P, Wissel B, Prairie YT (2009) Regulation of spatial and temporal variability of carbon flux in six hard-water lakes of the northern Great Plains. Limnol Oceanogr 54:2553-2564

FRIEND (1993) Flow regimes from international and network data. vol 1-3, Institute of Hydrology, Wallingford

Gupta N, Nafees SM, Jain MK, Kalpana S (2011) Assessment of groundwater quality of outer skirts of Kota City with reference to its potential of scale formation and corrosivity. E J Chem 8(3):1330-1338

Howden NJK, Neal C, Wheater HS, Kirk S (2010) Water quality of lowland, permeable Chalk rivers: the Frome and Piddle catchments, west Dorset, UK. Hydrol Res 41:75-91. doi:10.2166/nh. 2010.102

Humborg C, Conley DJ, Rahm L, Wulff F, Cociasu A, Ittekkot V (2000) Silicon retention in river basins: far reaching effects on biogeochemistry and aquatic food webs in coastal marine environments. Ambio 29:45-50

Hunt CW, Salisbury JE, Vandemark D (2011) Contribution of noncarbonate anions to total alkalinity and overestimation of $p \mathrm{CO}_{2}$ in New England and New Brunswick rivers. Biogeosciences 8:3069-3076. doi:10.5194/bg-8-3069-2011

Jansson M, Bergstro AK, Blomqvist MP, Drakare S (2000) Allochthonous organic carbon and phytoplankton/bacterioplankton production relationship in lakes. Ecology 81: 3250-3255

Jensen HS, Nielsen OI, Koch MS, de Vicente I (2009) Phosphorus release with carbonate dissolution coupled to sulfide oxidation in Florida Bay seagrass sediments. Limnol Oceanogr 54(5): $1753-1764$
Kling GW, Kipphut GW, Miller MC (1991) Arctic lakes and streams as gas conduits to the atmosphere: implications for tundra carbon budgets. Science 251:298-301

Krinner G (2003) Impact of lakes and wetlands on boreal climate. J Geophys Res 108:4520. doi:10.1029/2002JD002597

Krishnakumar P, Lakshumanan C, Pradeep Kishore V, Sundararajan M, Santhiya G, Chidambaram S (2014) Assessment of groundwater quality in and around Vedaraniyam, South India. Environ Earth Sci 71:2211-2225. doi:10.1007/s12665-013-2626-2

Kumar SS, Suriyanarayanan A, Panigrahi BS (2011) Studies of indices in cooling water system. Indian $\mathrm{J}$ Chem Technol 19:75-80

Melidis P, Akratos CS, Tsihrintzis VA, Trikilidou E (2007) Characterization of rain and roof drainage water quality in Xanthi, Greece. Environ Monit Assess 127:15-27. doi:10.1007/s10661006-9254-1

Paquay FS, Macenzie FT, Borges AV (2007) Carbon dioxide dynamics in rivers and coastal waters of the "big island" of Hawaii, USA, during baseline and heavy rain conditions. Aquat Geochem 13:1-18. doi:10.1007/s10498-006-9005-5

Riebesell U (2004) Effects of $\mathrm{CO}_{2}$ enrichment on marine phytoplankton. J Oceanogr 60:719-729

Rouse WR, Oswald CM, Binyamin J, Blanken PD, Schertzer WM, Spence C (2002) Interannual and seasonal variability of the surface energy balance and temperature of Central Great Slave Lake. J Hydrometeorol 4:720-730

Sheikh JA, Jeelani Gh, Gavali RS, Shah RA (2014) Weathering and anthropogenic influences on the water and sediment chemistry of Wular Lake, Kashmir Himalaya. Environ Earth Sci 71:2837-2846. doi:10.1007/s12665-013-2661-z

Sobek S, Tranvik LJ, Cole JJ (2005) Temperature independence of carbon dioxide supersaturation in global lakes. Global Biogeochem Cycle 19:GB2003. doi:10.1029/2004GB002264

Stets EG, Striegl RG, Aiken GR, Rosenberry DO, Winter TC (2009) Hydrologic support of carbon dioxide flux revealed by wholelake carbon budgets. J Geophys Res Biogeosci 114:G01008. doi:10.1029/2008JG000783

Striegl RG, Kortelainen P, Chanton JP, Wickland KP, Bugna GC, Rantakari M (2001) Carbon dioxide partial pressure and 13C content of north temperate and boreal lakes at spring ice melt. Limnol Oceanogr 46:941-945

Stumm W, Morgan JJ (1996) Aquatic chemistry, chemical equilibria and rates in natural waters, 3rd edn. Wiley, New York

Telmer K, Vezier J (1999) Carbon fluxes, $\mathrm{pCO}_{2}$ and substrate weathering in a large northern river basin, Canada: carbon isotope perspectives. Chem Geol 159:61-86

Toporowska M, Pawlik-Skowrońska B (2014) Four-year study on phytoplankton biodiversity in a small hypertrophic lake affected by water blooms of toxigenic cyanobacteria. Pol J Environ Stud 23(2):491-499

Tranvik LJ, Downing JA, Cotner JB, Loiselle SA, Striegl RG, Ballatore TJ, Dillon P, Finlay K, Fortino K, Knoll LB, Kortelainen PL, Kutser T, Larsen S, Laurion I, Leech DM, McCallister SL, McKnight DM, Melack JM, Overholt E, Porter JA, Prairie Y, Renwick WH, Roland F, Sherman BS, Schindler DW, Sobek S, Tremblay A, Vanni MJ, Verschoor AM, von Wachenfeldt E, Weyhenmeyera GA (2009) Lakes and reservoirs as regulators of carbon cycling and climate. Limnol Oceanogr 54(6):2298-2314

Valdivia FR (2006) Basin scale transport in stratified lakes and reservoirs: towards the knowledge of freshwater ecosystems. Limnetica 25(1-2):33-56

Von Wachenfeldt E, Tranvik LJ (2008) Sedimentation in boreal lakes - the role of flocculation of allochthonous dissolved organic matter in the water column. Ecosystems 11:803-814 
Wachniew P, Różański K (1997) Carbon budget of a mid-latitude, groundwater-controlled lake: isotopic evidence for the importance of dissolved inorganic carbon recycling. Geochim Cosmochim Acta 61(12):2453-2465

Wetzel RG (2001) Limnology, 3rd edn. Academic, USA
Weyhenmeyer GA, Karlsson J (2009) Nonlinear response of dissolved organic carbon concentrations in boreal lakes to increasing temperatures. Limnol Oceanogr 54:2513-2519

Wilgat T (1991) The Łęczna-Włodawa lakes. Stud Ośr Dok Fizj 19:56-74 